Meta

Journal des tradlucteurs

Translators' Journal

\title{
Translation in Africa: A Literary Perspective
}

\section{Stella M. A. Johnson}

Volume 34, numéro 4, décembre 1989

URI : https://id.erudit.org/iderudit/003267ar

DOI : https://doi.org/10.7202/003267ar

Aller au sommaire du numéro

Éditeur(s)

Les Presses de l'Université de Montréal

ISSN

0026-0452 (imprimé)

1492-1421 (numérique)

Découvrir la revue

Citer cet article

Johnson, S. M. A. (1989). Translation in Africa: A Literary Perspective. Meta, 34(4), 703-710. https://doi.org/10.7202/003267ar d'utilisation que vous pouvez consulter en ligne.

https://apropos.erudit.org/fr/usagers/politique-dutilisation/ 


\section{TRANSLATION IN AFRICA: A LITERARY PERSPECTIVE}

Stella M.A. Johnson

University of Lagos, Lagos, Nigeria

\section{INTRODUCTION}

Literature being a blend of thought and form, a literary translator is expected to take cognizance of the twin nature of the text to be translated. And since form is sometimes meaningful ${ }^{1}$, contrary to the claim that its role is only to provide aesthetic pleasure $^{2}$, it also follows that a literary translator should, in addition to conveying surface meanings, endeavour to highlight ideas embedded in the structure of the original text.

Evaluating literary translation is not very easy if one has to apply the prescriptions of translation theorists and practitioners. For example, Steiner (1975) advocates, among other things, a close examination of the translator's conception of the original text, the translator's linguistic competence, his sensitivity to the author and genre and the suitability of the text chosen. Simpson (1978) recommends a rigorous assessment of the translator's indebtedness to existing versions. D'Amelda (1980) suggests that due attention be paid to the translator's ability to impersonate or his/her ability to pastiche the style of the original text.

It is obvious from the above that attempting to assess literary translation in Africa in a single paper may be rather ambitious. We shall therefore narrow the scope of our study to (1) evidence and features of translation in some original texts (since translation is sometimes hampered by the fact that the original text is to some extent a translation), and (2) translators' strategies, options and deviations vis-à-vis aesthetic features and difficult segments of randomly selected literary translations.

\section{TRANSLATING AFRICAN LITERATURE}

One of the characteristics of African literature is the complexity of the literary corpus. African literature has three main strands: oral literature, literature in indigenous languages and literature in foreign languages.

All three categories have, to varying degrees, been rendered in other languages. Translation has been most useful for the retrieval, preservation and diffusion of oral literature since documents obtained from informants are mostly in African languages. Le Maître de la parole, Camara Laye's valedictory publication, is an acknowledged translation from Malinke to French of the epic of Sundjata who founded the empire of Mali. The book is based on a portion of Camara Laye's recorded interview with a prominent "Griot" and Arabic scholar named Babu Condé. Similarly, research on African oral literature entails translation. The conventional way of presenting research papers in this field is to juxtapose quotations from oral documents with their translations. Noteworthy examples are the publications of Adeboye Babalola and Wande Abimbola ${ }^{3}$.

African literature in foreign languages has so far been the most privileged in terms of translation, for it is the preference of well-seasoned non-African translators. Until recently, Africans have not been showing much interest in this particular domain. Some unique efforts which deserve recognition are the French translation of Achebe's Arrow of 
God by Irene Assiba d'Amelda and Olga Mahougbe Simpson, and the English translation of Mariama Ba's award-winning Une si longue lettre by Modupe Irele.

Efforts towards translating African literature into European languages are sometimes frustrated by lack of correspondences for cultural details which predominate in the African texts. The problem can be found even in original texts in which writers using a foreign medium have to rely on approximations of these cultural traits. For example, the word "co-épouse" used for lack of an alternative in Une si longue lettre does not convey the notion of seniority so vital in the typical African polygamous setting which Mariama $\mathrm{Ba}$ attempts to portray in the novel.

Lack of equivalents for aesthetic features derived from African languages is also a barrier. For example, whereas a Yoruba word such as "kiakia" can be adequately translated into Hausa by using the word "masamasa", the euphony of the word is lost in the English and French translations "quickly" and "vite" respectively. Similarly, the word "Tanfir" a Yoruba onomatopoiea literally meaning "slightly spicy" loses its effect when translated as "poudre de maïze" (cf. le Lion et la perle, the French translation of Wole Soyinka's The Lion and the Jewel).

Euphony is an important feature in some varieties of African poetry in which meaning, which is paramount to the translator, is sacrificed for pleasantness of sounds, play on words and tonal contrast ${ }^{4}$ as in the following partially meaningless Yoruba juvenile poem on number:

$\begin{array}{ll}\text { Ení bi ení } & \text { Translation } \\ \text { Eji bi èjì } & \text { One is like one } \\ \text { Eta ntagabá } & \text { Two is like two } \\ \text { Erin wòròkò } & \text { (meaningless) } \\ \text { (meaningless) }\end{array}$

In addition to being unable to convey all stylistic effects, translators of poetry have to grapple with the metric systems of their selected texts because strict adherence to or total deviation from the metric pattern of the original text may create a gap. The gap in translation is obviously wider if the original text is an oral document, the metric patterns of oral documents being less recognizable in transcriptions than in actual performances, in which metric gaps are filled by vocal elongations ${ }^{5}$.

The prominence of African thought patterns in African literary texts may also add to the problems of non-African translators. African thought patterns are consciously adopted by writers sometimes for plausibility in character depiction and sometimes for humour. In some texts by Aluko and Rotimi, some characters use what may be termed "Yoruba English", a literal translation of Yoruba into English, exemplified in utterances such as "Tell it to me", "They want to know what killed him" and "The king asked what is your name"6.

As stated earlier, African literary texts in foreign languages are to some extent translations. Some important language resources which the writers prefer to translate include the African proverb and metaphor. These features will be examined in one of the writings of Ola Rotimi.

\section{TRANSLATION OF PROVERBS AND METAPHORS}

In Africa, proverbs are used for elucidating ideas and impressing listeners. According to the Yorubas, proverbs are the spirit which gives vitality to discourse. This is copiously substantiated in The Gods Are Not to Blame, a play in which Ola Rotimi uses English translations of Yoruba proverbs for explication and eloquence, and to reinforce the action. Two of the examples which abound in the text are the speech of the first citizen and that of the second citizen in Act one: 


\section{First Citizen:}

When the chameleon brings forth a child, is not that child expected to dance?... As we have made you King act as King?.

\section{Second Citizen:}

When rain falls on the leopard, does it wash off its spots? Has the richness of Kingly life washed off the love of the King for his people? 8

The first segments of the above quotations are Ola Rotimi's English versions of the original Yoruba proverbs, while the remaining parts are added to extend the general meanings of the proverbs to specific situations.

With regard to techniques of translation, Rotimi's preferences are usually dictated by the literary genre. His preference with regard to proverbs is modal transposition, which the two examples just cited have in common. Whereas the original proverbs are in the indicative mood, Rotimi's versions are often in the interrogative mood, which is more dynamic and appropriate for drama.

Metaphors are also translated or adapted from Yoruba oral tradition for purposes similar to those ascribed to proverbs, but with different sets of techniques. For example, the description of Aderopo as "a tortoise, a coward, a conniving slippery maggot" 9 condenses the multiple negative roles of the tortoise in Yoruba moonlight tales ${ }^{10}$, while a proverb-based metaphor intended to emphasize the vigilance of a character reveals an entirely different process. The latter is found in Act two, Scene one in the following:

You are all-seeing. A partridge, you see with the face, you see with the whole body. ${ }^{11}$

If we compare Rotimi's version to the original proverb: "Toju tiye laparo fi nriran" (which literally means: "A partridge sees with the eyes and wings"), we would observe two major changes in the adaptation. The first is the reordering of the original sequence to emphasize meaning. The second is escalation of the original for intensity. The escalation has three processes: (1) concise interpretation (You are all seeing), (2) Metaphor (a partridge) and (3) elaboration (You see with the face, you see with the whole body). These changes make the adaptation more eloquent and more dramatic as in the previously highlighted examples.

In The Gods Are Not to Blame a larger proportion of the discourse is based on Yoruba oral tradition. About $25 \%$ of this material is retained in Yoruba because it consists of accessory elements (songs, conventional greetings, etc.) brought in merely for variety. In about $10 \%$ of the cultural content, the original and translations are juxtaposed for authenticity and comprehension as in research papers and publications on African oral literature.

Other aspects of Yoruba oral tradition having direct bearing on the action is either translated literally or adapted. This includes tales, praise-poems, herbal recipes, proverbs, and especially incantations, the amount of which is quite substantial. The majority of traditional Yorubas has an unflinching faith in the potency of incantations and their efficacy in exerting benevolent or detrimental magnetic influence. This is manifest in Act three, Scene one, where an old man uses the formula to disarm Odewale ${ }^{12}$. Although incantations do not seem effective for advancing action, they are a good booster for the cultural ingredient and poetic elegance.

\section{TRANSLATION OF SENGHOR AND ACHEBE}

We should now examine the translation of a text written by a pioneer Francophone writer, Léopold Sédar Senghor, whose predilection is poetry. 
Poetry is the least prolific genre in Africa. It is generally elusive and difficult to understand. Its translation is therefore not for a layman, but someone endowed with the gifts and vision of a poet.

Poems are visions of privileged moments which cannot be recaptured. In the translation of a poetry text, one often finds a gap in intensity, even when the translator is the poet himself. The gap is widened when another person undertakes the task, as observed in Craig Williams' translation of Senghor's poems ${ }^{13}$.

We must not fail to commend C. Williamson for his ability to retain the headlong movement which conveys Senghor's intention. The effusion of the original text is typical of Senghor when he writes on subjects like Negritude and pan-Africanism, which are very close to his bosom.

On the negative side, one perceives a conspicious lexical divergence between the original and the translation. While Senghor leans towards the specific, Craig generalises sometimes to the extent of eliminating essential implied meanings. Incidentally, his generalisation is not always justified by the recognised gap between English and French ${ }^{14}$ in terms of lexical precision or a desire to adhere to the metre of the original. Most often, Craig's generalisation is simply an assertion of his freedom of expression.

Translation of "stegomyas" as "mosquitoes" in a poem entitled " $L$ ' homme et la bête" (Ethiopiques) disregards the structural peculiarity of the breed of mosquito in the poet's mind and the implicit distinction between this carrier of yellow fever (a deadly disease for which Africa was nicknamed "the white man's grave") and anopheles which carries malaria.

Similarly, when "tamtam" is simply taken for "drum" (ibid.), the intended emphasis on the talking type of drum is discarded together with the euphony of the original word which is an example of onomatopoeia. The translator, however, adopted the word "tomtom" in a poem entitled "New York". "Water moccasins" does not convey the exact shade of meaning in Senghor's zoological term "trigonocéphales" (ibid.), which is a venomous snake of peculiar shape. The same remark applies to the rendering of "pagnes et boubous" as body clothes ("Laetare Jerusalem"). "Pagnes" and "boubous" are multipurpose African attire for men and women. Men sometimes use the "pagne" as bed clothes, and women put on the "boubou" for casual and formal outings. In the poem just cited, however, "boubou" and "pagne" feature as a metonymy to evoke manhood and womanhood, respectively.

In conclusion, one may assert that Craig's translation conveys surface meanings but lacks the lexical precision of the original text.

Another noteworthy effort on Senghor's poetry is by John Reed and Clive Wake ${ }^{15}$. In their version, cultural data are kept intact, thereafter assembled in an index of 72 items of varying occurrence. The entries relate to music, geographical location, people and dynasties, botany, language, cosmetics, warfare and onomastic. This "demarche" had the advantage of providing additional information to facilitate comprehension, the retention of the original metre of the verses and the Africanness of the lexis.

One of the translators' difficulties appears to have been occasioned by the poet's presentation of cultural details, for example the description of Nolive's complexion, which is partly a translation of a traditional concept:

Ma Négresse blonde d' huile de palme à la taille de plume

\section{English version:}

My Negress fair with palm oil slender as a plume ${ }^{16}$ 
The intended meaning is not "fair with palm oil" as the translators put it, but "fair as palm oil," as the rest of the verse suggests. Senghor's conception of Negritude as a synthesis of African and European culture is implicit in these lines in which he attempts to marry African aesthetic consciousness and European notions.

Nolive's description is also a striking example of the difference between elements of comparison in Europe and Africa. Whereas complexion is hardly ever associated with palm oil in Europe, it is a convention in Africa. Yorubas often say "Apón bí epo" or "Apón béporé" (fair as palm oil) and sometimes "Pupa bí òrombó" (light as orange). Approximation in these sayings is imputable to the limited range of words for colour in African languages including Serere, Senghor's mother tongue. In the majority of African languages, the word red stands for European nuances like tomato-red, fuchsia, garnet, maroon, oxide, rich-brown, yellow, shocking pink, russet, scarlet plus butter sweet and coppertones which are the closes to palm oil. The black colour is often taken for brown, coconut-brown, chocolate, sand, bronze and honey tone.

Another gap between Senghor's version and the translation of Reed and Wake is the insertion of punctuation marks and conjunctions where their omission is deliberate, for example in the following lines taken from "Congo":

Mère de toutes choses qui ont narine, des crocodiles des hippopotames

\section{English version:}

Mother of all things in whose nostrils is breath.

Mother of crocodiles and hippopotami ${ }^{17}$.

Although the English version sounds fine with the insertion of "and" between crocodile and hippopotami, the option for conventional punctuation significantly weakens the impetus which unfolds one of Senghor's aesthetic preoccupations.

Senghor seems to have been imbued with some of the tenets of surrealism, particularly the contention that language is given to man for spontaneous use 18 . His grammatical breaches, despite the poet's expertise in the subject, cannot be ascribed to any other factor besides the quest for spontaneity and momentary freedom from the constraints of language.

We shall now briefly comment on la Flèche de Dieu, a very successful translation of Achebe's third novel by Irene d'Amelda and Olga Simpson. The novel comprises nineteen chapters. Simpson translated the first ten and d'Amelda the rest.

The translation was highly commended at the inaugural conference of the Nigerian Association of Translators and Interpreters (NATI), which took place at the University of Lagos in 1980 . The project was said to have necessitated a great deal of research ${ }^{19}$, particularly on cultural details which inundate Achebe's narration, and which d'Amelda, in a paper entitled "The Experience of Translating Achebe's Arrow of God Into French", described as a major problem area. This acknowledgment underscores the cultural complexity of Africa and the need for translators of African literature to consult, collaborate and, whenever possible, undergo cultural induction.

The Arrow of God projects two contrasting worlds: the African and the European. One of its merits is said to be the skillful utilisation of the language of the latter to articulate the cultural realities of the former ${ }^{20}$. The search for originality and the choice of a tradition-conscious hero (Ezeulu) largely account for the accumulation of cultural references, explanations of which would have further enhanced the translation. Lack of a cultural index in the original text is indeed regrettable for, despite Achebe's conscious effort at making unfamiliar terms explicit in context and through frequency of occurrence, the meanings of several lexical items elude certain categories of readers. 
One of such elusive details, on which additional information should have been provided in a glossary or index, is the following reference to time-lag:

For three markets, Ibe could barely rise from his bed

\section{French version:}

Pendant trois semaines de marché, lbe put à peine se lever de son lit 21 .

Unlike other parts of the world, shopping is done at different intervals in traditional Africa. Three successive markets, which may mean a couple of days or a couple of weeks, is precisely one of those polyvalent concepts of African literature which need explanations or footnotes.

Footnotes are necessary for time-bound details whose implications may elude readers of an epoch too distant from that of the writer. For example the word "Tanfiri", to which we have earlier alluded (cf. Wole Soyinka's The Lion and the Jewel), may not make any sense to present-day Nigerian teenagers, not to talk of youths of other countries, because the refreshment which was illicitly hawked in Western Nigerian primary schools in those days has been replaced by modern cookies.

When the original text has footnotes, such notes may be built into the translation to make the latter more explicit. A step in this direction is Francis Price's handling of God's Bits of Wood, the English translation of Sembene Ousmane's les Bouts de bois de Dieu.

\section{CONCLUSION}

Many present-day African writers are unknown. Their works are consequently excluded from the catalogue of completed and on-going literary translations. The catalogue is a little showcase of masterpieces of eminent writers and texts which have won popular awards.

The paucity of texts so far translated is due partly to mercenary motivation in text selection, and partly to the attraction of specific genres as determined by their level of difficulty. In spite of its extensiveness, the novel seems to appeal more to translators than poetry, which requires a special sensitivity.

African literature in foreign languages, the so-called "bastard literature" 22 , has so far been the most privileged in terms of translation. It has also been the most accessible to European translators who, for a considerable length of time, maintained the monopoly of the exercise. Among those worthy of note for the translation of African literature in French are Gerald Moore and Peter Green for Mongo Beti, James Kirkup for Camara Laye, Craig Williamson, John Reed and Clive Wake for Léopold Sédar Senghor; Karen Chapman for Bernard Dadié; and Francis Price for Sembene Ousmane.

Very little has been done in translating African literature in African languages into other African languages. Some progress has, however, been recorded for the translation of this brand of African literature into European languages. A noteworthy effort is the French translation of the novels of D.O. Fagunwa (a celebrated Yoruba writer) by J.O. Abioye.

Given the attention which translator training is presently receiving in African institutions of higher learning and some sectors of African governments, it is certain that Africans will participate more substantially in literary translation in the near future and will, by so doing, contribute to the promotion of African literature beyond the confines of Africa. 


\section{Notes and References}

1. Jean Rousset (1961): Forme et signification, Paris, Corti.

2. Sigmund Freud (1971): les Mots d'esprit et leurs rapports avec l'inconscient, Paris, Gallimard, translated from the German by Marie Bonaparte.

3. See Form and Content of Ijala and Ifa: An Exposition of Ifa Literary Corpus.

4. A comment by Emeritus Prof. Adeboye Babalola in an interview he granted me in January 1985.

5. The conjecture was confirmed in research conducted on North African poetry with the aid of a pitch loudness processor designed by Prof. Jairazboy of UCLA. Details are contained in a paper presented by Abderahman Ayoud (De la métrique de la poésie orale: pour une méthode quantifiante) at the International Symposium on African oral literature in Yaounde in January 1985.

6. These literal translations give priority to Yoruba syntax. For example, the first utterance (see The Gods Are Not to Blame, Act 3, Scene 1, p. 43) may be analysed as follows:

7. Ola Rotimi (1971): The Gods Are Not to Blame, London, Oxford University Press, Act 1, Scene 1, p. 9.

\begin{tabular}{l|l|l|l|l}
\hline $\begin{array}{l}\text { Yoruba } \\
\text { English }\end{array}$ & Tell & it & to & me \\
\hline Yoruba & so & o & fun & mi \\
\hline & verb & $\begin{array}{l}\text { direct } \\
\text { object }\end{array}$ & $\begin{array}{l}\text { preposi- } \\
\text { tion }\end{array}$ & $\begin{array}{l}\text { indirect } \\
\text { object }\end{array}$ \\
\hline
\end{tabular}

8. Ibid., p. 10.

9. Ibid., p. 34

10. In Yoruba oral tradition, the tortoise is an intriguing animal that deceived and overcame bigger animals including the elephant.

11. The Gods Are Not to Blame, p. 26.

12. Ibid., p. 48 .

13. Craig Williamson (1976): Léopold Sédar Senghor: Selected Poems (Chants d'ombre, 1945; Hosties noires, 1948; Chants pour Naett, 1949; Ethiopiques, 1956 and Nocturnes, 1961), London, Rex Collings.

14. Vinay et Darbelnet (1958): Stylistique comparée du français et de l'anglais, Paris, Didier.

15. John Reed and Clive Wake (1976): Sédar Senghor: Prose and Poetry, London, Heinemann. See Also Senghor's Selected Poems by the same translators, London, Oxford University Press, 1965.

16. Reed and Wake (1965): Sédar Senghor, Oxford University Press, op. cit., p. 69 and Léopold Sédar Senghor (1956): Ethiopiques, Paris, Seuil, p. 35 (see "Chaka").

17. Ibid. (see "Congo", Senghor, Éthiopiques, p. 10, Reed and Wake, Oxford University Press), p. 65.

18. André Breton (1924): Manifeste du surréalisme, Paris, Gallimard, pp. $42-43$ and 46.

19. Control of data is partly the advantage of being residents of Nigeria during the translation exercise.

20. M.J.C. Echeruo (1975): "Chinua Achebe," in Bruce King and Kolawole Ogungbesan: A Celebration of Black and African Writing, Abu and Oxford University Press, ch. 12, pp. 150-163.

21. La Flèche de Dieu, p. 24 and The Arrow of God, p. 14.

22. Oyin Ogunba's presidential address entitled "A Bastard Literature and a Bastard Criticism," First Annual Conference of the Literary Society of Nigeria, University of Benin, September, 1980.

\section{BIBLIOGRAPHY}

ALBIR, Amparo Hurtado (1983): "Traduction trahison", Reflet, 6.

BRISLIN, Richard (ed.) (1976): Translation: Applications and Research, New York, Gardner Press.

BROWER, Reuben (1959): On Translation, Cambridge (MA), Harvard University Press.

CARY, Edmond (1957): "L'art de traduire," Babel, 3, pp. 89-91.

CATFORD, J.C.A. (1965): Linguistic Theory of Translation: An Essay on Applied Linguistics, London, Oxford University Press.

D'AMELDA, Irene (1980): "Literary Translation: The Experience of Translating Achebe's Arrow of God into French," paper presented at the inaugural conference of the Nigerian Association of Translators and Interpreters (NATT), University of Lagos, February.

DARBELNET, Jean (1969): "La traduction raisonnée," META, 14:3, pp. 135-140.

DARBELNET, Jean (1970): "Traduction littérale ou traduction libre?" META, 15:2, pp. 88-94.

DARBELNET, Jean (1977): "Niveau de traduction," Babel, mars.

FERENCIK, Jan (1970): "De la spécification de la traduction de l'œuvre dramatique," in Holmes. 
FLAMAND, Jacques (1983): Écrire et traduire, Ottawa, Vermillon.

HOLMES, James S. (ed.): The Nature of Translation, The Hague, Mouton, pp. 144-149.

JOHNSON, M.A. (1984): "Translation and Literary Adaptation," META, 29:4, pp. 421-425.

LADMIRAL, J.R. (1979): Traduire: Théorème pour la traduction, Paris, Payot.

LEFEVRE, André (1975): Translating Poestry: Seven Strategies and a Blueprint, Assan/Amsterdam, Vam Gorcum.

MOUNIN, Georges (1963): les Problèmes théoriques de la traduction, Paris, Gallimard.

MOUNIN, Georges (1976): Linguistique et traduction, Brussels, Dessart et Mardaga.

NIDA, Eugene (1964): Towards a Science of Translation, Leiden, E.J. Brill.

NIDA, Eugene (1969): The Theory and Practice of Translation, Leiden, E.J. Brill.

SIMPSON, E. (1975): "Methodology in Translation Criticism," META, 20:4, pp. 251-262.

SIMPSON, E.: "Evaluating Translation: Objective Criteria," paper presented at WAMLA 11, University of Legon, Accra, Dec. 28, 1977 to Jan. 3, 1978.

STEINER, George (1975): After Babel: Aspects of Language and Translation, London, Oxford University Press.

STEINER, T.R. (1975): English Translation Theory: 1650-1800, Amsterdam, Van Grocum.

VINAY, J.-P. and J. DARBELNET (1958): Stylistique comparée du français et de l'anglais, Paris, Didier. 